\title{
Psychological Impact of Health Risk Communication and Social Media on College Students During the COVID-19 Pandemic: Cross-Sectional Study
}

\author{
Mengyao Li, PhD; Li Liu, PhD; Yilong Yang, PhD; Yang Wang, PhD; Xiaoshi Yang, PhD; Hui Wu, PhD
}

China Medical University, Shenyang, China

\section{Corresponding Author:}

Hui $\mathrm{Wu}, \mathrm{PhD}$

China Medical University

No 77 Puhe Road

Shenyang North New Area

Shenyang, 110122

China

Phone: 8618900910568

Email: $\underline{\text { hwu@cmu.edu.cn }}$

\section{Abstract}

Background: The outbreak of COVID-19 began in 2019 and is expected to impact the psychological health of college students. Few studies have investigated the associations among health risk communication, social media, and psychological symptoms during a major pandemic.

Objective: The aim of this research was to assess the prevalence of psychological symptoms among college students and explore their associations with health risk communication and social media.

Methods: A web-based survey was distributed through the Wenjuanxing platform among Chinese college students from March 3-15, 2020. In addition to demographics, information on health risk communication and social media was collected, and the Symptom Checklist 90 Phobia and Health Anxiety Inventory subscale was used to assess psychological symptoms among 1676 college students in China. Multivariable logistic regression was performed to examine these independent risk factors.

Results: The prevalence of panic and health anxiety was $17.2 \%$ (288/1676) and 24.3\% (408/1676), respectively. Regarding risk communication, understanding the risk of COVID-19 (odds ratio [OR] 0.480, 95\% CI 0.367-0.627) was a protective factor against panic. Knowledge of prognosis (OR 0.708, 95\% CI 0.551-0.910), preventive measures (OR 0.380, 95\% CI 0.195-0.742), and wearing face masks (OR $0.445,95 \%$ CI $0.230-0.862$ ) were shown to be protective factors in predicting health anxiety. Perceived lethality (OR 1.860, 95\% CI 1.408-2.459), being affected by the global spread (OR 1.936, 95\% CI 1.405-2.669), and impact on social contacts (OR 1.420, 95\% CI 1.118-1.802) were identified as significant risk factors associated with health anxiety. In terms of social media, trust in mainstream media (OR $0.613,95 \%$ CI $0.461-0.816$ ) was considered to be a protective factor against health anxiety.

Conclusions: There was a high prevalence of psychological symptoms among college students. Health risk communication and social media use were important in predicting psychological symptoms, especially health anxiety. Scientific and evidence-based information should be reported by social media platforms. Web-based consultation and intervention measures should be the focus of future studies.

(J Med Internet Res 2020;22(11):e20656) doi: 10.2196/20656

\section{KEYWORDS}

COVID-19; anxiety; panic; health risk; communication; social media

\section{Introduction}

The COVID-19 pandemic is a global health threat [1]. The World Health Organization (WHO) has declared the COVID-19 outbreak to be a public health emergency of international concern [2]. The COVID-19 pandemic has spread worldwide and has had a significant impact on public health, governments, and social systems [3]. As of April 26, 2020, the number of global cumulative confirmed cases had exceeded 2,800,000, and the cumulative death toll was 192,971 [4]. 
The pandemic is not only leading to rapidly increasing numbers of confirmed cases and deaths but is also having a psychological impact on patients and health care workers who are exposed to COVID-19 [5]. Although most people are free from COVID-19 infection, they are being psychologically impacted by the COVID-19 pandemic [6,7]. People who are quarantined may have numerous psychological symptoms, such as anxiety, depression, panic, guilt, and stress [8]. Panic and anxiety are two common psychological symptoms experienced during the outbreak; this is likely related to the limited knowledge about COVID-19 and its highly infectious nature [8-11]. These psychological symptoms may cause adverse events and further contribute to social instability and racism [12].

College students are a key population of concern during the COVID-19 pandemic. The college years are a peak period for psychological symptom onset [13]. The high prevalence of COVID-19, home quarantine measures, shortage of masks during the initial stage of the pandemic, and delays in opening schools, colleges, and universities are expected to aggravate the psychological symptoms of college students. The mental health of college students is significantly affected during public health emergencies [14]. The WHO indicated that almost $90 \%$ of the world`s students (more than 1,500,000,000 children and young people) have been affected by nationwide school closures [15]. It is necessary to help college students maintain and develop their psychological health during the pandemic.

Researchers have increasingly acknowledged the importance of consistent, clear, and effective health risk communication throughout a pandemic [16]. Risk communication refers to an interactive process of exchanging information among individuals, groups, and institutions [17]. Health risk communication has a critical impact on the spread of pandemics and may help public health officials improve pandemic strategies and messaging [18]. Effective risk communication contributes to the implementation of precautionary behaviors, especially when new pandemic infectious disease risks arise in the phase when no treatment is available [19]. Based on protection motivation theory [20] and knowledge-attitude-practice theory [21], risk perception, correct knowledge, understanding, attitudes, and skills [16,22,23] are key to promoting and implementing preventive behavior [19,24]. Health risk communication is also important in maintaining psychological health. Emotional experiences during a hazardous event can influence individuals' evaluation of the negative outcomes of that event [25]. Previous studies have found that health risk communication can be a predictor of postdisaster mental health $[26,27]$. Risk perception is associated with mental symptoms, and dread of risk can increase the risk of mental symptoms [28]. Risk perception is associated with psychological health in earthquake survivors [29]. However, the association between health risk communication and psychological health during a pandemic has not yet been established, especially among college students.

Mass media plays a critical role during new and rapidly spreading global health risks [30]. In China, official departments provide daily updates about surveillance and active cases through social media [10]. This information helps the public improve their awareness of the outbreak. In addition, in a study by Gao et al [31], 82\% of participants were found to frequently engage with social media. In addition to mainstream media, websites release and transfer COVID-19-related information [10]. The proliferation of internet-based health news encourages the referencing of media and academic articles, which may exaggerate the strength of results and mislead the public [32]. Contradictory, doubtful (untrustworthy), false, or misleading information may lead to public panic and, in turn, cause mental health symptoms [33]. These untrusted media sources heighten confusion and fearmongering $[8,32]$ and cause anxiety and panic among students. As young people, college students are willing to obtain information on the internet. Therefore, college students may access more information sources and more complex content and thus may be more seriously affected [34,35]. This phenomenon may have a significant psychological impact on college students.

Thus, the COVID-19 pandemic may place a great psychological burden on college students worldwide. Health risk communication and trusted sources of information regarding COVID-19 are essential to prevent excessive panic and anxiety and to manage the outbreak in a scientific and effective way. The aims of this study are to explore the prevalence of panic and anxiety among college students and to identify the relationships among health risk communication, social media, and these two psychological symptoms. By identifying factors associated with negative psychological impacts, we hope that future research and interventions can be developed from our findings.

\section{Methods}

\section{Ethics Statement}

The procedures used in the current study were approved by the Committee on Human Experimentation of China Medical University (YDJK2020022). All subjects voluntarily enrolled in this research. Informed consent was provided by each participant.

\section{Study Design}

This cross-sectional survey was conducted from March 3-15, 2020. During this period, the total number of confirmed cases of COVID-19 exceeded 80,000 in China [36]. Chinese college students were invited to participate in a web-based survey though the Wenjuanxing platform. In total, 1676 college students participated in this study.

\section{Measurement of Panic}

Panic was measured using the Phobia subscale of the self-reported Symptom Checklist 90 (SCL-90) [37]. This scale consists of 7 items that mainly cover phobia symptoms, with an emphasis on situations with limited availability of help and avoidance behavior. The score for each item ranges from 0-4. If a score is $>2$ (above average), some phobia symptoms may be present [38]. The Cronbach $\alpha$ coefficient of the total scale was .925.

\section{Measurement of Health Anxiety}

The Health Anxiety Inventory (HAI) was used to measure health anxiety [39]. The HAI is an 18-item scale, and each item has 4 
answer options ranging from 0 ("I do not") to 3 ("I spend most of my time") [39]. The presence of health anxiety is defined as a total score $\geq 15$ [40]. The Cronbach $\alpha$ coefficient of the total scale was .818 .

\section{Measurement of Health Risk Communication of COVID-19}

Health risk communication of COVID-19 was measured through two aspects: COVID-19-related perceptions and knowledge of preventive behaviors.

The COVID-19-related perceptions included knowledge of the prognosis of COVID-19, understanding of the risk of COVID-19, perceived lethality of COVID-19, perceived severity of COVID-19, feeling that it is difficult to protect oneself from being affected by the pandemic, and being affected by the global spread. Each item had 5 answer options: very low, low, moderate, high, and very high. The responses were subsequently categorized as moderate (moderate/low/very low) or high (high/very high).

Knowledge of preventive behaviors included knowledge of preventive measures, awareness of handwashing, awareness of wearing a face mask, and impact of home quarantine on social contacts. The questions regarding preventive measures had 5 response options: very low, low, moderate, high, and very high. The responses were subsequently categorized as moderate (moderate/low/very low) or high (high/very high). The questions about handwashing, wearing a face mask, and the impact of home quarantine on social contacts had 5 response options: strongly disagree, slightly disagree, moderate, slightly agree, and strongly agree. The responses were subsequently categorized as no (strongly disagree/slightly disagree/moderate) or yes (slightly agree/strongly agree).

\section{Measurement of Social Media Sources of COVID-19 Information}

Social media use was measured by asking which sources the participant used to obtain COVID-19-related information during the last month. These sources included WeChat, Sina Weibo, websites, television, newspapers, broadcast, government notices, or family members or friends. Trusted information sources were identified by asking "What do you think is the most trusted source of information regarding COVID-19?" The answers were divided into two groups: mainstream media and nonmainstream media.

\section{Demographic Characteristics}

The demographic factors examined included gender, major, monthly disposable income, region, number of cases in the participant's province, and year of study. Gender was divided into male and female. Major was divided into medicine-related major and other. Year was categorized as Year 1/2 and Year $3 / 4 / 5$. Monthly disposable income was categorized into three groups: $\leq 1000$ yuan ( $\leq$ US \$151), 1001-2000 yuan (US $\$ 162-303$ ), and >2000 yuan (>US \$303). Region was divided into rural and urban. Confirmed cases per province was divided into $<1000$ and $\geq 1000$.

\section{Statistical Analysis}

First, comparisons between participants with and without panic or health anxiety were performed using chi-square tests for categorical variables. Next, a multivariable logistic regression analysis was conducted to identify which determinants contributed most to the likelihood of panic or health anxiety. Logistic regression analyses were used to explain the associations between the prevalence of panic, health anxiety, social media, and health risk communication after controlling for covariates. The aforementioned variables were all entered into the multivariate model. The Nagelkerke $R^{2}$ value was used as the coefficient of determination. Missing values were replaced with mean values. The Hosmer-Lemeshow test was used to examine the goodness-of-fit of the model, and a $P$ value $>.05$ indicated acceptable fitness. Statistical analysis was conducted using SPSS 21.0 (IBM Corp), and a two-tailed $P$ value <.05 was viewed as statistically significant.

\section{Results}

\section{Participant Characteristics}

Among the 1676 students, the prevalence of panic was $17.2 \%$ $(n=288)$, and the prevalence of health anxiety was $24.3 \%$ $(n=408)$. The mean age of the students was 20.17 years (SD 1.497). As shown in Tables 1-3, most of the college students were female $(1088 / 1676,64.9 \%)$. Most of the participants $(1220 / 1676,72.8 \%)$ were in Year 1 or Year 2. In total, $1235 / 1676$ students $(73.7 \%)$ were from urban areas. According to our results, only $121 / 1676$ students (7.2\%) were from Hubei, Guangdong, Henan, Zhejiang, or Hunan Province, each of which had more than 1000 confirmed cases of COVID-19. 
Table 1. Demographic factors of the respondents and differences between panic and health anxiety $(\mathrm{N}=1676)$.

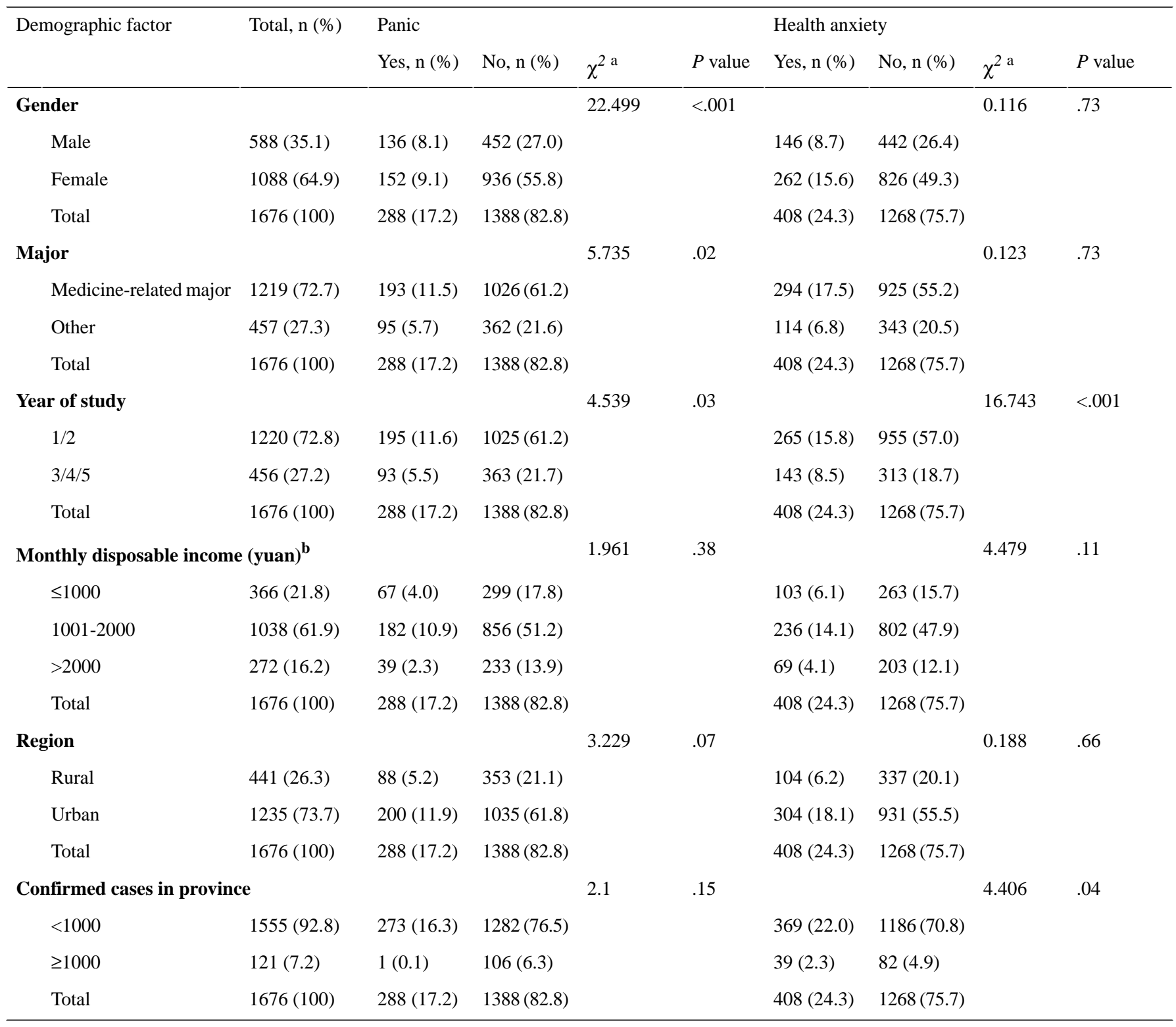

${ }^{\mathrm{a}}$ All degrees of freedom are 1 except for monthly disposable income, for which the degrees of freedom are 2 .

${ }^{\mathrm{b}} 1$ yuan=US \$0.14 on March 3, 2020. 
Table 2. Knowledge of COVID-19-related risks and protective measures reported by the respondents and differences between panic and health anxiety $(\mathrm{N}=1676)$.

\begin{tabular}{|c|c|c|c|c|c|c|c|c|c|}
\hline \multirow[t]{2}{*}{ Health risk knowledge } & \multirow[t]{2}{*}{ Total, n (\%) } & \multicolumn{4}{|l|}{ Panic } & \multicolumn{4}{|c|}{ Health anxiety } \\
\hline & & Yes, n (\%) & No, $\mathrm{n}(\%)$ & $\chi_{1}^{2}$ & $P$ value & Yes, $\mathrm{n}(\%)$ & No, $\mathrm{n}(\%)$ & $\chi_{1}^{2}$ & $P$ value \\
\hline \multicolumn{10}{|c|}{ Perception of COVID-19-related information } \\
\hline \multicolumn{3}{|c|}{ Knowledge of prognosis } & & 0.009 & .92 & & & 15.479 & $<.001$ \\
\hline Moderate & $514(30.7)$ & $89(5.3)$ & $425(25.4)$ & & & $157(9.4)$ & $357(21.3)$ & & \\
\hline High & $1162(69.3)$ & 199 (11.9) & $963(57.5)$ & & & $251(15.0)$ & $911(54.4)$ & & \\
\hline Total & $1676(100)$ & $288(17.2)$ & $1388(82.8)$ & & & $408(24.3)$ & $1268(75.7)$ & & \\
\hline \multicolumn{2}{|c|}{ Understanding of the risk } & & & 36.618 & $<.001$ & & & 3.601 & .06 \\
\hline Moderate & $782(46.7)$ & $181(10.8)$ & $601(35.9)$ & & & $207(12.4)$ & $575(34.3)$ & & \\
\hline High & $894(53.3)$ & $107(6.3)$ & $787(47.0)$ & & & $201(12.0)$ & $693(41.3)$ & & \\
\hline Total & $1676(100)$ & $288(17.2)$ & $1388(82.8)$ & & & $408(24.3)$ & $1268(75.7)$ & & \\
\hline \multicolumn{2}{|l|}{ Perceived lethality } & & & 0.004 & .95 & & & 49.315 & $<.001$ \\
\hline Moderate & $1300(77.6)$ & $223(13.3)$ & $1077(64.3)$ & & & $265(15.8)$ & $1035(61.8)$ & & \\
\hline High & $376(22.4)$ & $65(3.9)$ & $311(18.6)$ & & & $143(8.5)$ & $233(13.9)$ & & \\
\hline Total & $1676(100)$ & $288(17.2)$ & $1388(82.8)$ & & & $408(24.3)$ & $1268(75.7)$ & & \\
\hline \multicolumn{4}{|c|}{ Feeling that it is difficult to protect oneself from the pandemic } & 4.658 & .03 & & & 22.688 & $<.001$ \\
\hline Moderate & $1482(88.4)$ & $244(14.6)$ & $1238(73.9)$ & & & $334(19.9)$ & $1148(68.5)$ & & \\
\hline High & 194 (11.6) & $44(2.6)$ & $150(8.9)$ & & & $74(4.4)$ & $120(7.2)$ & & \\
\hline Total & $1676(100)$ & $288(17.2)$ & $1388(82.8)$ & & & $408(24.3)$ & $1268(75.7)$ & & \\
\hline \multicolumn{2}{|l|}{ Perceived severity } & & & 3.443 & .06 & & & 21.551 & $<.001$ \\
\hline Moderate & $1228(73.3)$ & $225(13.4)$ & $1011(60.3)$ & & & $265(15.8)$ & $971(57.9)$ & & \\
\hline High & 448 (26.7) & $63(3.8)$ & $377(22.5)$ & & & $143(8.5)$ & 297 (17.7) & & \\
\hline Total & $1676(100)$ & $288(17.2)$ & $1388(82.8)$ & & & $408(24.3)$ & $1268(75.7)$ & & \\
\hline \multicolumn{2}{|c|}{ Affected by global spread } & & & 2.579 & .11 & & & 24.624 & $<.001$ \\
\hline Moderate & $399(23.8)$ & $58(3.5)$ & $341(20.3)$ & & & $60(3.6)$ & $339(20.2)$ & & \\
\hline High & $1277(76.2)$ & $230(13.7)$ & $1047(62.5)$ & & & $348(20.8)$ & $929(55.4)$ & & \\
\hline Total & $1676(100)$ & $288(17.2)$ & $1388(82.8)$ & & & $408(24.3)$ & $1268(75.7)$ & & \\
\hline \multicolumn{10}{|c|}{ Knowledge of preventive behaviors } \\
\hline \multicolumn{3}{|c|}{ Knowledge of preventive measures } & & 3.566 & .06 & & & 17.235 & $<.001$ \\
\hline Moderate & $43(2.6)$ & $12(0.7)$ & $31(1.8)$ & & & $22(1.3)$ & $21(1.3)$ & & \\
\hline High & $1633(97.4)$ & $276(16.5)$ & $1357(81.0)$ & & & $386(23.0)$ & $1247(74.4)$ & & \\
\hline Total & $1676(100)$ & $288(17.2)$ & $1388(82.8)$ & & & $408(24.3)$ & $1268(75.7)$ & & \\
\hline \multicolumn{2}{|c|}{ Awareness of handwashing } & & & 10.416 & .001 & & & 1.269 & .26 \\
\hline No & $70(4.2)$ & $22(1.3)$ & $48(2.9)$ & & & $21(1.3)$ & $49(2.9)$ & & \\
\hline Yes & $1606(95.8)$ & $266(15.9)$ & $1340(80.0)$ & & & $387(23.1)$ & $1219(72.7)$ & & \\
\hline Total & $1676(100)$ & $288(17.2)$ & $1388(82.8)$ & & & $408(24.3)$ & $1268(75.7)$ & & \\
\hline \multicolumn{3}{|c|}{ Awareness of wearing face masks } & & 4.452 & .04 & & & 8.025 & .005 \\
\hline No & $45(2.7)$ & $13(0.8)$ & $32(1.9)$ & & & $19(1.1)$ & $26(1.6)$ & & \\
\hline Yes & $1631(95.8)$ & $275(16.4)$ & $1356(80.9)$ & & & $389(23.2)$ & $1242(74.1)$ & & \\
\hline Total & $1676(100)$ & $288(17.2)$ & $1388(82.8)$ & & & $408(24.3)$ & $1268(75.7)$ & & \\
\hline \multicolumn{3}{|c|}{ Impact of home quarantine on social contacts } & & 1.588 & .21 & & & 18.277 & $<.001$ \\
\hline No & $1045(62.4)$ & $189(11.8)$ & $856(51.1)$ & & & $218(13.0)$ & $827(49.3)$ & & \\
\hline
\end{tabular}




\begin{tabular}{|c|c|c|c|c|c|c|c|c|c|}
\hline \multirow[t]{2}{*}{ Health risk knowledge } & \multirow[t]{2}{*}{ Total, n (\%) } & \multicolumn{4}{|l|}{ Panic } & \multicolumn{4}{|c|}{ Health anxiety } \\
\hline & & Yes, n (\%) & No, n (\%) & $\chi_{1}^{2}$ & $P$ value & Yes, n (\%) & No, n $(\%)$ & $\chi_{1}^{2}$ & $P$ value \\
\hline Yes & 631 (37.6) & $99(5.9)$ & $532(31.7)$ & & & $190(11.3)$ & $441(26.3)$ & & \\
\hline Total & $1676(100)$ & $288(17.2)$ & $1388(82.8)$ & & & $408(24.3)$ & $1268(75.7)$ & & \\
\hline
\end{tabular}

Table 3. Number of social media information sources and trust in sources reported by the respondents and differences between panic and health anxiety $(\mathrm{N}=1676)$.

\begin{tabular}{|c|c|c|c|c|c|c|c|c|c|}
\hline \multirow[t]{2}{*}{ Social media source } & \multirow[t]{2}{*}{ Total, n (\%) } & \multicolumn{4}{|l|}{ Panic } & \multicolumn{4}{|c|}{ Health anxiety } \\
\hline & & Yes, n (\%) & No, n $(\%)$ & $\chi_{1}^{2}$ & $P$ value & Yes, n (\%) & No, n (\%) & $\chi_{1}^{2}$ & $P$ value \\
\hline \multicolumn{2}{|c|}{ Number of information sources } & & & 1.082 & .30 & & & 0.711 & .40 \\
\hline$\leq 3$ & $745(44.5)$ & $136(8.1)$ & $609(36.3)$ & & & $174(104)$ & $571(34.1)$ & & \\
\hline$\geq 4$ & $931(55.5)$ & $152(9.0)$ & $779(46.5)$ & & & $234(14.0)$ & 697 (41.6) & & \\
\hline Total & $1676(100)$ & $288(17.2)$ & $1388(82.8)$ & & & $408(24.3)$ & $1268(75.7)$ & & \\
\hline Trust in information & & & & 6.641 & .01 & & & 20.757 & $<.001$ \\
\hline Nonmainstream & $301(18)$ & $67(4.0)$ & $234(14.0)$ & & & $104(6.2)$ & $197(11.8)$ & & \\
\hline Mainstream & $1375(82)$ & $221(13.2)$ & $1154(67.9)$ & & & $304(18.1)$ & $1071(63.9)$ & & \\
\hline Total & $1676(100)$ & $288(17.2)$ & $1388(82.8)$ & & & $408(24.3)$ & $1268(75.7)$ & & \\
\hline
\end{tabular}

Relationships Among Demographic Factors, Health Risk Communication, Social Media, and Panic

With respect to demographic factors, the groups showed significant differences in the distributions of gender, major, and year of study in the univariate analyses according to chi-square tests. No significant differences were found for monthly disposable income, region, or cases per province between the two groups.

Students who understood the risks of COVID-19 and felt less affected by the outbreak had lower panic levels. With respect to preventive knowledge, students who were aware that handwashing and wearing face masks can prevent COVID-19 had less panic. Regarding social media, students who trusted mainstream media information had less panic.

\section{Relationships Among Demographic Factors, Social Media, Health Risk Communication, and Health Anxiety}

With respect to demographic factors, the groups showed significant differences in the distributions of year of study and cases per province in the univariate analyses according to chi-square tests. No significant differences were found for gender, major, monthly disposable income, or region between the two groups.

Regarding COVID-19-related perception, students who had knowledge of the prognosis of the disease and felt less affected by the outbreak had lower health anxiety. Students who thought
COVID-19 was lethal and severe and who were affected by the global spread had more health anxiety. In terms of preventive knowledge, students who had knowledge of preventive measures and were aware that wearing face masks could prevent COVID-19 had less health anxiety. Students who considered that their social contacts were affected by home quarantine had more health anxiety. Regarding social media, participants who believed mainstream information was more trustworthy had less health anxiety.

\section{Risk Factors for Panic}

Multivariable logistic regression analysis was conducted to identify which determinants contributed most to the likelihood of developing panic. The results of the unadjusted model and a model adjusting for potentially confounding demographic factors are reported. The confounders included in the adjusted model were major, gender, and year. The Nagelkerke pseudo- $R^{2}$ values for the unadjusted and adjusted models were 0.048 and 0.074, respectively. The Hosmer-Lemeshow tests demonstrated adequate fitness for the unadjusted $\left(\chi^{2}{ }_{4}=2.733, P=.60\right)$ and adjusted $\left(\chi_{8}^{2}=5.790, P=.67\right)$ models. The variables in the adjusted model explained $7.4 \%$ of the variance in panic. The main effects of the adjusted model were similar to the crude results except for the awareness of handwashing. As shown in the adjusted model, a better understanding of the risk of COVID-19 (odds ratio [OR] 0.480, 95\% CI 0.367-0.627) was identified as a significant protective factor for panic. These data are shown in Table 4. 
Table 4. Results of logistic regression of risk factors for panic.

\begin{tabular}{|c|c|c|c|c|}
\hline \multirow[t]{2}{*}{ Variable } & \multicolumn{2}{|l|}{ Unadjusted model $^{\mathrm{a}}$} & \multicolumn{2}{|l|}{ Adjusted model $^{\mathrm{b}}$} \\
\hline & $\mathrm{OR}^{\mathrm{c}}(95 \% \mathrm{CI})$ & $P$ value & OR $(95 \% \mathrm{CI})$ & $P$ value \\
\hline \multicolumn{5}{|l|}{ COVID-19-related perception } \\
\hline $\begin{array}{l}\text { Understanding the risk of COVID-19 } \\
\text { (high vs moderate) }\end{array}$ & $0.476(0.366-0.621)$ & $<.001$ & $0.480(0.367-0.627)$ & $<.001$ \\
\hline $\begin{array}{l}\text { Felt it was difficult to protect oneself from the } \\
\text { pandemic (high vs moderate) }\end{array}$ & $1.279(0.881-1.855)$ & .20 & $1.243(0.853-1.812)$ & .26 \\
\hline \multicolumn{5}{|l|}{ Knowledge of preventive behaviors } \\
\hline Awareness of handwashing (yes vs no) & $0.533(0.292-0.975)$ & .04 & $0.619(0.336-1.143)$ & .13 \\
\hline Awareness of wearing face masks (yes vs no) & $0.892(0.412-1.942)$ & .77 & $0.933(0.427-2.034)$ & .86 \\
\hline \multicolumn{5}{|l|}{ Information source } \\
\hline $\begin{array}{l}\text { Trusted information (mainstream media vs } \\
\text { nonmainstream media) }\end{array}$ & $0.738(0.538-1.013)$ & .06 & $0.792(0.574-1.092)$ & .15 \\
\hline \multicolumn{5}{|l|}{ Covariates } \\
\hline Gender (female vs male) & $\mathrm{N} / \mathrm{A}^{\mathrm{d}}$ & N/A & $0.526(0.403-0.687)$ & $<.001$ \\
\hline Year of study (3/4/5 vs $1 / 2)$ & N/A & N/A & $1.268(0.951-1.692)$ & .11 \\
\hline Major (medicine-related major vs other) & N/A & N/A & $0.720(0.538-0.962)$ & .03 \\
\hline
\end{tabular}

${ }^{\text {a }}$ Nagelkerke $R^{2}=0.048$.

${ }^{\mathrm{b}}$ Nagelkerke $R^{2}=0.074$.

${ }^{\mathrm{c}} \mathrm{OR}$ : odds ratio.

${ }^{\mathrm{d}} \mathrm{N} / \mathrm{A}$ : not applicable.

\section{Risk Factors for Health Anxiety}

The results of the unadjusted model and a model adjusting for potentially confounding demographic factors are reported in Table 5. The confounders included in the adjusted model were cases per province and year of study. The Nagelkerke pseudo- $R^{2}$ values for the unadjusted and adjusted models were 0.110 and 0.119 , respectively. The Hosmer-Lemeshow tests demonstrated adequate fitness for the unadjusted $\left(\chi_{8}^{2}=3.610, P=.89\right)$ and adjusted $\left(\chi_{7}^{2}=3.080, P=.88\right)$ models. The variables in the adjusted model explained $11.9 \%$ of the variance in health

anxiety. The main effects of the adjusted model were similar to the crude results except for perceived severity. As shown in the adjusted model, knowledge of prognosis (OR 0.708, 95\% CI 0.551-0.910), knowledge of preventive measures (OR 0.380, 95\% CI 0.195-0.742), awareness of wearing a face mask (OR $0.445,95 \%$ CI $0.230-0.862$ ), and trust in mainstream media (OR $0.613 ; 95 \%$ CI 0.461-0.816) were shown to be protective factors in predicting health anxiety. Perceived lethality (OR $1.860,95 \%$ CI 1.408-2.459), being affected by the global spread (OR 1.936, 95\% CI 1.405-2.669), and impact on social contacts (OR 1.420, 95\% CI 1.118-1.802) were significant risk factors for health anxiety. 
Table 5. Results of logistic regression of risk factors for health anxiety.

\begin{tabular}{|c|c|c|c|c|}
\hline \multirow[t]{2}{*}{ Variable } & \multicolumn{2}{|l|}{ Unadjusted model $^{\mathrm{a}}$} & \multicolumn{2}{|l|}{ Adjusted model $^{\mathrm{b}}$} \\
\hline & $\mathrm{OR}^{\mathrm{c}}(95 \% \mathrm{CI})$ & $P$ value & OR $(95 \% \mathrm{CI})$ & $P$ value \\
\hline \multicolumn{5}{|l|}{ COVID-19-related perception } \\
\hline Knowledge of prognosis (high vs moderate) & $0.698(0.544-0.896)$ & .005 & $0.708(0.551,0.910)$ & .007 \\
\hline Perceived lethality (high vs moderate) & $1.898(1.438-2.506)$ & $<.001$ & $1.860(1.408,2.459)$ & $<.001$ \\
\hline $\begin{array}{l}\text { Felt it was difficult to protect oneself from the } \\
\text { pandemic (high vs moderate) }\end{array}$ & $1.231(0.866-1.750)$ & .25 & $1.232(0.865-1.753)$ & .25 \\
\hline Perceived severity (high vs moderate) & $1.309(1.003-1.708)$ & .047 & $1.302(0.996-1.701)$ & .05 \\
\hline Affected by global spread (high vs moderate) & $2.014(1.464-2.772)$ & $<.001$ & $1.936(1.405-2.669)$ & $<.001$ \\
\hline \multicolumn{5}{|l|}{ Knowledge of preventive behaviors } \\
\hline $\begin{array}{l}\text { Knowledge of preventive measures } \\
\text { (high vs moderate) }\end{array}$ & $0.374(0.193-0.728)$ & .004 & $0.380(0.195-0.742)$ & .005 \\
\hline Awareness of wearing face masks (yes vs no) & $0.439(0.228-0.844)$ & .014 & $0.445(0.230-0.862)$ & .02 \\
\hline $\begin{array}{l}\text { Impact of home quarantine on social contacts } \\
\text { (yes vs no) }\end{array}$ & $1.434(1.131-1.818)$ & .003 & $1.420(1.118-1.802)$ & .004 \\
\hline \multicolumn{5}{|l|}{ Social media } \\
\hline $\begin{array}{l}\text { Trusted information } \\
\text { (mainstream media vs nonmainstream media) }\end{array}$ & $0.611(0.460-0.812)$ & 0.001 & $0.613(0.461-0.816)$ & .001 \\
\hline \multicolumn{5}{|l|}{ Covariates } \\
\hline $\begin{array}{l}\text { Number of confirmed cases in province }(\geq 1000 \\
\text { vs }<1000)\end{array}$ & $N / A^{d}$ & N/A & $1.405(0.927-2.219)$ & .11 \\
\hline Year of study ( $3 / 4 / 5$ vs $1 / 2)$ & N/A & N/A & $1.453(1.129-1.870)$ & .004 \\
\hline
\end{tabular}

${ }^{\mathrm{a}}$ Nagelkerke $R^{2}=0.110$.

${ }^{\mathrm{b}}$ Nagelkerke $R^{2}=0.119$.

${ }^{\mathrm{c}} \mathrm{OR}$ : odds ratio.

${ }^{\mathrm{d}} \mathrm{N} / \mathrm{A}$ : not applicable.

\section{Discussion}

\section{Principal Findings}

This study investigated the prevalence of panic and health anxiety among college students and explored the associations of health risk communication and social media with panic and health anxiety during the pandemic outbreak. Our results indicated that the prevalence of panic was $17.2 \%(288 / 1676)$ and the prevalence of health anxiety was $24.3 \%$ (408/1676). Previous studies have also reported that pandemics can trigger psychological symptoms $[31,41,42]$. If a pandemic constitutes an uncertain and threatening situation, it is more likely to trigger psychological symptoms. During pandemics, the number of people whose mental health is affected is greater than the number of people infected with the disease [43]. It is necessary to implement psychological interventions for college students during the COVID-19 pandemic.

Health risk communication was found to be important in predicting psychological symptoms among college students. With respect to risk perception, understanding the risk of COVID-19 was the only influencing factor for panic. Understanding the risk of COVID-19 could help relieve panic among college students. Similarly, knowledge of the prognosis of COVID-19 was a protective factor in predicting health anxiety. Individuals behave in a more reticent and conservative manner when they feel threatened by disease [44]. Awareness of risk may help students take effective measures to prevent infection and avoid panic and anxiety. Understanding the risk, prognosis, and routes of COVID-19 infection further decreases panic and health anxiety. Our results are in line with previous studies. Receiving more health information is correlated with lower levels of psychological distress [45]. Properly understanding information is important for reducing negative psychological responses brought on by inaccurate perceptions [46]. Clear communication involving regular, accurate updates on the COVID-19 outbreak plays a critical role in developing psychological health [6]. At present, there are still limited effective treatments and vaccines for COVID-19, and the high infectivity, lethality, and global spread of the disease are causing health anxiety among college students.

Knowledge of preventive behaviors was another aspect of health risk communication that significantly predicted health anxiety among college students. Similarly, knowledge of preventive measures and of wearing a face mask were protective factors in predicting health anxiety. Accurate knowledge helped individuals react to and positively combat the outbreak, and it resulted in less negative emotion. Knowledge and guidance 
about preventive behaviors are important factors in mitigating the spread of COVID-19 [47] and allaying unrealistic or excessive psychological anxiety [48]. Almost 37.6\% of students $(631 / 1676)$ felt that their social contacts were impacted by the home quarantine measures. The loss of freedom and increase of boredom had marked effects. Limitation of social contacts has a series of negative effects on psychological health. The etiology of anxiety as an illness includes a number of interacting biological, psychological, and social factors [49]. Individuals with better social networks are less likely to report anxiety symptoms [50]. Using class-based social groups may be able to improve college students' positive psychology and promote a positive atmosphere to enhance strong-tie relationships [51]. Even during the pandemic outbreak, social support plays a critical role in alleviating students' negative psychological symptoms, including anxiety [14]. Students can keep in touch with their friends or relatives on the web or by telephone to maintain social connections.

Social media played a critical role in psychological health. Students who believed that mainstream information was more trustworthy experienced less anxiety. Social media was the primary means of distributing information. Based on our results, $55 \%$ of students obtained COVID-19-related information in more than 4 ways. Mass media exposure to "infomedia" through social media platforms can create anxiety because rumors, "fake news," and conspiracy theories make it difficult to find trustworthy information [52]. Misinformation has caused anxiety and even hampered the response to the outbreak. Students spend a lot of time on the internet, and they are more likely to be misguided and experience triggering of anxiety symptoms. Appropriate guidance from authorities, meanwhile, can prevent individuals from overreacting to the disease and engaging in excessively avoidant behaviors [53]. Official public health organizations provide accurate information on measures to avoid COVID-19 [54], and the information is considered trustworthy and reliable [55]. During the pandemic, most people want to receive information from municipal health services, health care providers, and official media sources [56]. In the face of public health emergencies, accurate and authoritative information is important for relieving psychological symptoms among college students.

\section{Implications}

There are several implications of this study for clinical practitioners and policy makers. First, more attention should be paid to the psychological health of college students during the COVID-19 pandemic, and protective measures must be increased. Regardless of whether they were infected, students experienced psychological impacts from the outbreak. The delayed college start, uncertainty, and potential negative impact on academic progression may enhance the psychological burden on college students. Second, social media should be held responsible for providing correct and evidence-based information. Our study indicated that $55.5 \%$ (931/1676) of students obtained COVID-19-related information from more than four sources. Social media reporting can have both positive and negative consequences, and it had a strong influence on the psychological health of students. Information on social media platforms should be managed to quickly reduce the spread of fear and uncertainty and enhance public trust in public health measures [52]. Third, social isolation should be avoided. Imposed quarantine, including separation from friends or relatives and a departure from usual daily routines, is an unpleasant experience [57]. Additionally, social isolation caused an increase in anxiety. The need for social support has increased during the current pandemic. It is necessary to communicate socially via the internet or by telephone during the COVID-19 pandemic. Finally, health risk communication is essential during the outbreak. Based on our research, almost all students possessed knowledge related to the prevention of COVID-19. While the severity of the pandemic can trigger psychological symptoms in college students, risk perception promotes appropriate practices among students [58]. Our results indicated that $95.8 \%$ of college students $(1606 / 1676)$ believed that preventive behaviors were effective. These behaviors provided the students with a sense of security and decreased their fear and anxiety.

\section{Limitations}

Several limitations should be considered in this study. First, conclusions on causality cannot be drawn due to the cross-sectional design. Second, given the use of a web-based survey, there may be some response bias. Third, the explained variance was low.

\section{Conclusion}

Psychological symptoms among college students were found to be at high levels during the COVID-19 pandemic. Understanding the risk of COVID-19 was a protective factor for panic. Trust in mainstream media, knowledge of preventive measures of COVID-19, and knowledge of its prognosis were protective factors for anxiety. However, perceived lethality, the global spread, and impact on social contacts were risk factors for health anxiety. Effective health risk communication and scientific and evidenced-based information should be reported through social media. The psychological health of college students should be considered. Future research should focus on intervention measures to ensure college students' psychological well-being during a global pandemic outbreak.

\section{Acknowledgments}

The authors would like to thank all the participants in this study. This research received no external funding.

\section{Authors' Contributions}

MYL and HW conceived and designed the investigation. LL, YW, and XSY performed the investigation. MYL and YLY analyzed the data. MYL wrote the paper. All authors read and approved the final manuscript. 


\section{Conflicts of Interest}

None declared.

\section{References}

1. Wang C, Horby PW, Hayden FG, Gao GF. A novel coronavirus outbreak of global health concern. Lancet 2020 Feb 15;395(10223):470-473 [FREE Full text] [doi: 10.1016/S0140-6736(20)30185-9] [Medline: $\underline{31986257]}$

2. Mahase E. China coronavirus: WHO declares international emergency as death toll exceeds 200. BMJ 2020 Jan 31;368:m408. [doi: 10.1136/bmj.m408] [Medline: 32005727]

3. Pan X, Ojcius DM, Gao T, Li Z, Pan C, Pan C. Lessons learned from the 2019-nCoV epidemic on prevention of future infectious diseases. Microbes Infect 2020 Mar;22(2):86-91 [FREE Full text] [doi: 10.1016/j.micinf.2020.02.004] [Medline: 32088333]

4. Coronavirus disease (COVID-19) pandemic. World Health Organization. URL: $\underline{\text { https://www.who.int/emergencies/diseases/ }}$ novel-coronavirus-2019 [accessed 2020-04-26]

5. Lai J, Ma S, Wang Y, Cai Z, Hu J, Wei N, et al. Factors Associated With Mental Health Outcomes Among Health Care Workers Exposed to Coronavirus Disease 2019. JAMA Netw Open 2020 Mar 02;3(3):e203976 [FREE Full text] [doi: $\underline{10.1001 / j a m a n e t w o r k o p e n .2020 .3976}$ [ [Medline: $\underline{\text { 32202646] }}$

6. Xiang Y, Yang Y, Li W, Zhang L, Zhang Q, Cheung T, et al. Timely mental health care for the 2019 novel coronavirus outbreak is urgently needed. Lancet Psychiat 2020 Mar;7(3):228-229 [FREE Full text] [doi: 10.1016/S2215-0366(20)30046-8] [Medline: 32032543]

7. Duan L, Zhu G. Psychological interventions for people affected by the COVID-19 epidemic. Lancet Psychiat 2020 Apr;7(4):300-302 [FREE Full text] [doi: 10.1016/S2215-0366(20)30073-0] [Medline: 32085840]

8. Brooks SK, Webster RK, Smith LE, Woodland L, Wessely S, Greenberg N, et al. The psychological impact of quarantine and how to reduce it: rapid review of the evidence. Lancet 2020 Mar 14;395(10227):912-920 [FREE Full text] [doi: 10.1016/S0140-6736(20)30460-8] [Medline: 32112714]

9. Shigemura J, Ursano RJ, Morganstein JC, Kurosawa M, Benedek DM. Public responses to the novel 2019 coronavirus (2019-nCoV) in Japan: Mental health consequences and target populations. Psychiatry Clin Neurosci 2020 Apr;74(4):281-282 [FREE Full text] [doi: 10.1111/pcn.12988] [Medline: 32034840]

10. Bao Y, Sun Y, Meng S, Shi J, Lu L. 2019-nCoV epidemic: address mental health care to empower society. Lancet 2020 Feb 22;395(10224):e37-e38 [FREE Full text] [doi: 10.1016/S0140-6736(20)30309-3] [Medline: $\underline{\text { 32043982] }}$

11. Wang C, Pan R, Wan X, Tan Y, Xu L, Ho CS, et al. Immediate Psychological Responses and Associated Factors during the Initial Stage of the 2019 Coronavirus Disease (COVID-19) Epidemic among the General Population in China. Int J Environ Res Public Health 2020 Mar 06;17(5):1729 [FREE Full text] [doi: 10.3390/ijerph17051729] [Medline: 32155789 ]

12. Devakumar D, Shannon G, Bhopal SS, Abubakar I. Racism and discrimination in COVID-19 responses. Lancet 2020 Apr 11;395(10231):1194 [FREE Full text] [doi: 10.1016/S0140-6736(20)30792-3] [Medline: 32246915]

13. de Girolamo G, Dagani J, Purcell R, Cocchi A, McGorry PD. Age of onset of mental disorders and use of mental health services: needs, opportunities and obstacles. Epidemiol Psychiatr Sci 2012 Mar;21(1):47-57. [doi:

10.1017/s2045796011000746] [Medline: 22670412]

14. Cao W, Fang Z, Hou G, Han M, Xu X, Dong J, et al. The psychological impact of the COVID-19 epidemic on college students in China. Psychiatry Res 2020 May;287:112934 [FREE Full text] [doi: 10.1016/j.psychres.2020.112934] [Medline: 32229390]

15. Coronavirus disease 2019 (COVID-19) Situation Report-77. World Health Organization. URL: https://www.who.int/docs/ default-source/coronaviruse/situation-reports/20200406-sitrep-77-covid-19.pdf?sfvrsn=21d1e632 2 [accessed 2020-04-06]

16. Jehn M, Kim Y, Bradley B, Lant T. Community knowledge, risk perception, and preparedness for the 2009 influenza A/H1N1 pandemic. J Public Health Manag Pract 2011;17(5):431-438. [doi: 10.1097/PHH.0b013e3182113921] [Medline: 21788781]

17. National Research Council (US) Committee on Risk Perception and Communication. Improving risk communication. Washington, DC: National Academy Press; 1989.

18. Henrich N, Holmes B. The public's acceptance of novel vaccines during a pandemic: a focus group study and its application to influenza H1N1. Emerg Health Threats J 2009;2:e8 [FREE Full text] [doi: 10.3134/ehtj.09.008] [Medline: 22460289]

19. Brug J, Aro AR, Richardus JH. Risk perceptions and behaviour: towards pandemic control of emerging infectious diseases: international research on risk perception in the control of emerging infectious diseases. Int J Behav Med 2009;16(1):3-6 [FREE Full text] [doi: $10.1007 / \mathrm{s} 12529-008-9000-\mathrm{x}$ ] [Medline: 19127440 ]

20. Rogers RW. Cognitive and physiological processes in fear appeals and attitude change: A revised theory of protection motivation. In: Cacioppo JT, Petty R, editors. Social Psychophysiology: A Sourcebook. New York, NY: Guilford Press; 1983:153-177.

21. Ajilore K, Atakiti I, Onyenankeya K. College students' knowledge, attitudes and adherence to public service announcements on Ebola in Nigeria: Suggestions for improving future Ebola prevention education programmes. Health Educ J 2017 Jun 15;76(6):648-660. [doi: 10.1177/0017896917710969] 
22. Murakami M, Nakatani J, Oki T. Evaluation of Risk Perception and Risk-Comparison Information Regarding Dietary Radionuclides after the 2011 Fukushima Nuclear Power Plant Accident. PLoS One 2016;11(11):e0165594 [FREE Full text] [doi: 10.1371/journal.pone.0165594] [Medline: 27802304]

23. Hano MC, Baghdikian CL, Prince S, Lazzarino E, Hubbell B, Sams E, et al. Illuminating Stakeholder Perspectives at the Intersection of Air Quality Health Risk Communication and Cardiac Rehabilitation. Int J Environ Res Public Health 2019 Sep 26;16(19):3603. [doi: 10.3390/ijerph16193603] [Medline: $\underline{31561473]}$

24. Renner B, Schupp H. The perception of health risks. In: The Oxford Handbook of Health Psychology. New York, NY: Oxford University Press; 2011.

25. Siegrist M, Sütterlin B. Human and nature-caused hazards: the affect heuristic causes biased decisions. Risk Anal 2014 Aug;34(8):1482-1494. [doi: 10.1111/risa.12179] [Medline: 24576178]

26. Tseng MM, Lin Y, Hu F, Cheng T. Risks perception of electromagnetic fields in Taiwan: the influence of psychopathology and the degree of sensitivity to electromagnetic fields. Risk Anal 2013 Nov;33(11):2002-2012. [doi: 10.1111/risa.12041] [Medline: 23551091]

27. McArdle SC, Rosoff H, John RS. The dynamics of evolving beliefs, concerns emotions, and behavioral avoidance following 9/11: a longitudinal analysis of representative archival samples. Risk Anal 2012 Apr;32(4):744-761. [doi: 10.1111/j.1539-6924.2012.01814.x] [Medline: 22500650]

28. Nukui H, Murakami M, Midorikawa S, Suenaga M, Rokkaku Y, Yabe H, et al. Mental Health and Related Factors of Hospital Nurses. Asia Pac J Public Health 2017 Mar;29(2_suppl):161S-170S. [doi: 10.1177/1010539516682589] [Medline: 28330404]

29. Xu J, Dai J, Rao R, Xie H. The association between exposure and psychological health in earthquake survivors from the Longmen Shan Fault area: the mediating effect of risk perception. BMC Public Health 2016 May 18;16:417 [FREE Full text] [doi: 10.1186/s12889-016-2999-8] [Medline: 27193051]

30. Schmälzle R, Häcker F, Renner B, Honey CJ, Schupp HT. Neural correlates of risk perception during real-life risk communication. J Neurosci 2013 Jun 19;33(25):10340-10347 [FREE Full text] [doi: 10.1523/JNEUROSCI.5323-12.2013] [Medline: 23785147]

31. Gao J, Zheng P, Jia Y, Chen H, Mao Y, Chen S, et al. Mental health problems and social media exposure during COVID-19 outbreak. PLoS One 2020;15(4):e0231924 [FREE Full text] [doi: 10.1371/journal.pone.0231924] [Medline: 32298385]

32. Ippolito G, Hui DS, Ntoumi F, Maeurer M, Zumla A. Toning down the 2019-nCoV media hype-and restoring hope. Lancet Respir Med 2020 Mar;8(3):230-231 [FREE Full text] [doi: 10.1016/S2213-2600(20)30070-9] [Medline: 32146924]

33. Ashrafi-Rizi H, Kazempour Z. Information Typology in Coronavirus (COVID-19) Crisis; a Commentary. Arch Acad Emerg Med 2020;8(1):e19 [FREE Full text] [Medline: 32185370]

34. Cheng C, Jun H, Liang B. Psychological health diathesis assessment system: a nationwide survey of resilient trait scale for Chinese adults. Stud Psychol Behav 2014;12:735-742.

35. Qiu J, Shen B, Zhao M, Wang Z, Xie B, Xu Y. A nationwide survey of psychological distress among Chinese people in the COVID-19 epidemic: implications and policy recommendations. Gen Psychiatr 2020;33(2):e100213 [FREE Full text] [doi: 10.1136/gpsych-2020-100213] [Medline: 32215365]

36. The latest situation of the novel coronavirus pneumonia epidemic as of 24:00 on March 15. Webpage in Chinese. National Health Commission of the People's Republic of China. URL: http://www.nhc.gov.cn/xcs/yqtb/202003/ 114113d25c1d47aabe68381e836f06a8.shtml [accessed 2020-11-13]

37. Derogatis L. SCL-90-R: Administration, Scoring, and Procedures Manual. Minneapolis, MN: NCS Pearson; 1996.

38. Wei Y, Li H, Wang H, Zhang S, Sun Y. Psychological Status of Volunteers in a Phase I Clinical Trial Assessed by Symptom Checklist 90 (SCL-90) and Eysenck Personality Questionnaire (EPQ). Med Sci Monit 2018 Jul 17;24:4968-4973 [FREE Full text] [doi: 10.12659/MSM.909524] [Medline: 30015333]

39. Salkovskis PM, Rimes KA, Warwick HMC, Clark DM. The Health Anxiety Inventory: development and validation of scales for the measurement of health anxiety and hypochondriasis. Psychol Med 2002 Jul;32(5):843-853. [doi: 10.1017/s0033291702005822] [Medline: 12171378]

40. Zhang Y, Liu R, Li G, Mao S, Yuan Y. The reliability and validity of a Chinese-version Short Health Anxiety Inventory: an investigation of university students. Neuropsychiatr Dis Treat 2015;11:1739-1747 [FREE Full text] [doi: 10.2147/NDT.S83501] [Medline: 26213472]

41. Liao Q, Cowling BJ, Lam WWT, Ng DMW, Fielding R. Anxiety, worry and cognitive risk estimate in relation to protective behaviors during the 2009 influenza A/H1N1 pandemic in Hong Kong: ten cross-sectional surveys. BMC Infect Dis 2014 Mar 27;14:169 [FREE Full text] [doi: 10.1186/1471-2334-14-169] [Medline: 24674239]

42. Ji D, Ji Y, Duan X, Li W, Sun Z, Song X, et al. Prevalence of psychological symptoms among Ebola survivors and healthcare workers during the 2014-2015 Ebola outbreak in Sierra Leone: a cross-sectional study. Oncotarget 2017 Feb 21;8(8):12784-12791 [FREE Full text] [doi: 10.18632/oncotarget.14498] [Medline: 28061463]

43. Reardon S. Ebola's mental-health wounds linger in Africa. Nature 2015 Mar 05;519(7541):13-14. [doi: 10.1038/519013a] [Medline: 25739606]

44. Schaller M, Park J, Kenrick D. Human evolution and social cognition. In: Oxford Handbook of Evolutionary Psychology. Oxford, UK: Oxford University Press; 2007. 
45. Ho CS, Chee CY, Ho RC. Mental Health Strategies to Combat the Psychological Impact of COVID-19 Beyond Paranoia and Panic. Ann Acad Med Singap 2020 Mar 16;49(3):155-160 [FREE Full text] [Medline: $\underline{32200399]}$

46. Li S, Wang Y, Xue J, Zhao N, Zhu T. The Impact of COVID-19 Epidemic Declaration on Psychological Consequences: A Study on Active Weibo Users. Int J Environ Res Public Health 2020 Mar 19;17(6):2032 [FREE Full text] [doi: 10.3390/ijerph17062032] [Medline: 32204411]

47. Basch CH, Hillyer GC, Meleo-Erwin ZC, Jaime C, Mohlman J, Basch CE. Preventive Behaviors Conveyed on YouTube to Mitigate Transmission of COVID-19: Cross-Sectional Study. JMIR Public Health Surveill 2020 Apr 02;6(2):e18807 [FREE Full text] [doi: 10.2196/18807] [Medline: $\underline{\text { 32240096] }}$

48. Levin PJ, Gebbie EN, Qureshi K. Can the health-care system meet the challenge of pandemic flu? Planning, ethical, and workforce considerations. Public Health Rep 2007;122(5):573-578 [FREE Full text] [doi: 10.1177/003335490712200503] [Medline: 17877303 ]

49. McCutcheon VV. Toward an Integration of Social and Biological Research. Soc Serv Rev 2006 Mar;80(1):159-178 [FREE Full text] [doi: 10.1086/499087] [Medline: 20414476]

50. Levula A, Harré M, Wilson A. The Association Between Social Network Factors with Depression and Anxiety at Different Life Stages. Community Ment Health J 2018 Aug;54(6):842-854. [doi: 10.1007/s10597-017-0195-7] [Medline: 29127564]

51. Chang S, Lin Y, Lin C, Chang H, Chong PP. Promoting positive psychology using social networking sites: a study of new college entrants on Facebook. Int J Environ Res Public Health 2014 Apr 29;11(5):4652-4663 [FREE Full text] [doi: 10.3390/ijerph110504652] [Medline: 24785540]

52. Depoux A, Martin S, Karafillakis E, Preet R, Wilder-Smith A, Larson H. The pandemic of social media panic travels faster than the COVID-19 outbreak. J Travel Med 2020 May 18;27(3):taaa031 [FREE Full text] [doi: 10.1093/jtm/taaa031] [Medline: 32125413 ]

53. Schaller M, Murray DR, Bangerter A. Implications of the behavioural immune system for social behaviour and human health in the modern world. Philos Trans R Soc Lond B Biol Sci 2015 May 26;370(1669):20140105 [FREE Full text] [doi: 10.1098/rstb.2014.0105] [Medline: 25870392]

54. Hua J, Shaw R. Corona Virus (COVID-19) "Infodemic" and Emerging Issues through a Data Lens: The Case of China. Int J Environ Res Public Health 2020 Mar 30;17(7):2309 [FREE Full text] [doi: 10.3390/ijerph17072309] [Medline: 32235433]

55. Covolo L, Mascaretti S, Caruana A, Orizio G, Caimi L, Gelatti U. How has the flu virus infected the Web? 2010 influenza and vaccine information available on the Internet. BMC Public Health 2013 Jan 29;13:83 [FREE Full text] [doi:

10.1186/1471-2458-13-83] [Medline: 23360311]

56. van der Weerd W, Timmermans DR, Beaujean DJ, Oudhoff J, van Steenbergen JE. Monitoring the level of government trust, risk perception and intention of the general public to adopt protective measures during the influenza A (H1N1) pandemic in The Netherlands. BMC Public Health 2011 Jul 19;11:575 [FREE Full text] [doi: 10.1186/1471-2458-11-575] [Medline: 21771296]

57. Usher K, Bhullar N, Jackson D. Life in the pandemic: Social isolation and mental health. J Clin Nurs 2020 Aug;29(15-16):2756-2757. [doi: 10.1111/jocn.15290] [Medline: 32250493]

58. Zhong B, Luo W, Li H, Zhang Q, Liu X, Li W, et al. Knowledge, attitudes, and practices towards COVID-19 among Chinese residents during the rapid rise period of the COVID-19 outbreak: a quick online cross-sectional survey. Int J Biol Sci 2020;16(10):1745-1752 [FREE Full text] [doi: 10.7150/ijbs.45221] [Medline: 32226294]

\author{
Abbreviations \\ HAI: Health Anxiety Inventory \\ OR: odds ratio \\ SCL-90: Symptom Checklist 90 \\ WHO: World Health Organization
}

Edited by $G$ Eysenbach; submitted 25.05.20; peer-reviewed by E Mollard, C Kruse, K Mathiasen; comments to author 13.06.20;
revised version received 06.08.20; accepted 26.10.20; published 18.11 .20
Please cite as:
Li M, Liu L, Yang Y, Wang Y, Yang X, Wu H
Psychological Impact of Health Risk Communication and Social Media on College Students During the COVID-19 Pandemic:
Cross-Sectional Study
J Med Internet Res 2020;22(11):e20656
URL: $\underline{\text { http://www.jmir.org/2020/11/e20656/ }}$
doi: $\underline{10.2196 / 20656}$
PMID: $\underline{3108308}$


(CMengyao Li, Li Liu, Yilong Yang, Yang Wang, Xiaoshi Yang, Hui Wu. Originally published in the Journal of Medical Internet Research (http://www.jmir.org), 18.11.2020. This is an open-access article distributed under the terms of the Creative Commons Attribution License (https://creativecommons.org/licenses/by/4.0/), which permits unrestricted use, distribution, and reproduction in any medium, provided the original work, first published in the Journal of Medical Internet Research, is properly cited. The complete bibliographic information, a link to the original publication on http://www.jmir.org/, as well as this copyright and license information must be included. 